\title{
THE ANALYSIS OF MARKETING CONCEPT IMPLEMENTATION IN DOMESTIC ENTERPRISES
}

UDC: 005:658(497.11)

Review Paper

\author{
Dejan ĐORĐEVIĆ ${ }^{1}$, Dragan ĆOĆKALO ${ }^{2}$, Srđan BOGETIĆ ${ }^{3}$ \\ ${ }^{1}$ University of Novi Sad, Technical faculty "Mihajlo Pupin” Zrenjanin, 23000 Zrenjanin, Đure Đakovića bb, \\ Republic of Serbia \\ ${ }^{2}$ University of Novi Sad, Technical faculty ”Mihajlo Pupin” Zrenjanin, 23000 Zrenjanin, Đure Đakovića bb, \\ Republic of Serbia \\ E-mail: dragan.cockalo@tfzr.rs \\ ${ }^{3}$ Belgrade Business School, 11000 Belgrade, Kraljice Marije 73, Republic of Serbia
}

Paper received: 21.10.2016.; Paper accepted: 04.11.2016.

\begin{abstract}
Global markets and modern business conditions require from enterprises to change their business philosophy and ways of behaviour in their business practice. Nowadays, in IT society, knowledge has become the basic resource. Marketing enables knowledge management by making possibilities for increasing knowledge productivity of other business functions in enterprises. Relationship marketing signifies a considerable advance in marketing approach, going from thinking exclusively about competition and conflict categories towards the categories of collaboration and interdependence. Domestic enterprises are facing problems with achieving competitive abilities on global markets and one of significant causes of this phenomenon is inappropriate implementation of marketing concept and modern methods and techniques of marketing management. This paper presents current global trends in theory and practice of marketing and marketing management along with critical analysis and recommendations for improving marketing practice in domestic enterprises.
\end{abstract}

Keywords: Marketing, Competitiveness, Global market, Management, Knowledge.

\section{INTRODUCTION}

Business environment has been changing permanently. The changes are under the strong influence of technological progress and the process of global market unification. These changes are permanent and business organizations have to make models of behaviour in relation to the observed and anticipated changes.

The changes in business environment are more and more expressed and intensified. The causes of these changes can be found in intensive technological development, the changes in competitive relations in the late $90 \mathrm{~s}$ and in the effects of the World economic crisis from 2008. The world has come into the new economic stadium, so national economies became closely connected and independent.
Business organizations that want to keep competitive ability in the long run ought to pay more attention to changes in the environment. According to Kotler (2009), the fact is that we are entering the new era of turbulence. Turbulence is a new normality. Stability is disappearing and the possibility of predicting events is decreased, so the society is exposed to the action of forces that caused the turbulence. Business turbulence assumes unpredictable and fast changes in internal or external environment of business organizations which affect their organizational structure.

The most outstanding management trends today are: globalization, technology, responsibility and corporate social responsibility and environmental protection. International economic relations are globalized - international economic flows go beyond the borders of individual countries. The world is becoming one market. Internationally 
oriented enterprises are getting more significant. According to some authors (Acharol and Kotler, 2012), globalization is continuing feverishly with implacable tempo. The countries such as China and India, along with enhancing the consumption base, are competing with developed world countries.

The main consequences of market globalization are increasingly aggressive competition on the global level and the danger caused by narrow market identification. Global competitiveness is becoming more intensive, agressive and noticeable. Market globalization has affected the changes in understanding and achieving competitive advantage.

Technology is the most dynamic development factor. The world has stepped into Information era whose essence is in communication, leaving the Industrial one behind. Fast technological changes ask for a new philosophical approach in studying enterprise management, which assumes permanent following up and long-term comprehension of market changes and technology development.

Hamel (2009) said that fast changes, short-time advantages, disruptive technologies, revolutionary competitors, disturbed markets, allmighty clients and rebellious share holders represent the challanges of the 21 st century that are putting on test the expected limitations of the organization world wide, revealing the imperfections of the management model which cannot keep pace with time.

New business conditions characterized by fast technological progress, market globalization, unification of customers' requirements and the increase of different interest groups' requirements are demanding from enterprises to accept totally new definition of business decisions and organization. Management has to be adjusted to customers' needs and the requirements coming from the environment.

\section{MODERN COMPREHENSION OF MARKETING}

Market changes affect most directly the way of thinking related to enterprise management. Successful business in modern economy is determined by the ability of enterprises to respond to the requirements set by the markets. If business is not characterized by permanent monitoring of market requirements and finding out adequite responses that will satisfy choosey customers, it is not possible to develop and improve enterprises.

Competition has been internationalized in most industries, so enterprises enter the markets through global strategies. In order to achieve competitive success enterprises must have competitive advantage in the form of lower costs or product differentiation. Furthermore, it is necessary to achieve competitive advantage through long-term provision of high quality products and services and permanent innovation of products and services.

Brooks and Little (1997) defined a new model of market performance marked as relationship marketing while they were studying market appearance of enterprises in new, global circumstances. This model is based on:

- Database Management,

- Interactive Marketing Communication and

- Network Marketing.

Marketing based on Database represents an organized set of data on individual customers, current or potential ones, including geographical, demografic, psycho-graphic data, as well as the data related to behaviour during the consumption process. Database is used for locating potential customers or clients, as well as for creating targeted marketing communication and sale efforts. Interactive marketing represents a set of interactive relations, mostly at the level of personal communication, aided by Information Technology. Network marketing represents a set of connections and relations, mostly of strategic nature both at personal level and the relationship level among enterprises. It is most often about making strategic alliances and partnerships among the enterprises belonging to a particular branch.

This model starts from a strategic focus on customers and the relations and links originated from customers' requirements in relation to an organization, and it finishes by the analysis of customers' loyalty and satisfaction as an integral part of permanent mutual relationship building up. The clue for understanding this pattern is in creating a set of relationships between an enterprise and its environment.

According to Kotler (2004), the basic characteristics of relationship marketing are the following ones: 
- It is more oriented towards partners and customers than products,

- It is more focused on development and keeping current customers than finding out new ones,

- It is more relied on multi-functional teams than the work at sector level,

- It is more relied on listening and learning than talking.

Relationship Marketing signifies an important paradigmatic step forward in marketing approach, going exclusively from thinking in competition and conflict categories towards thinking in the categories of interdependence and collaboration. It recognizes the importance of different participants - suppliers, employees, distributors, dealers, retailers, who collaborate in order to deliver the best value to targeted customers.

When speaking about marketing and market development, two types of marketing practice can be observed - vertical marketing and lateral marketing. Vertical marketing functions within a determined and defined market and is based on segmentation and positioning strategy. It means that the existing products or services are adjusted and various sub-types and sub-variations are made.

According to Kotler and de Bes (2005), lateral marketing is a working process which, when applied on the existing products or services, produces innovative new products and services that cover currently uncovered needs, situations or target groups. It is therefore a process which offers great possibilities for creating new categories of products or even markets.

Lateral marketing has its results in the process of lateral thinking which was developed by the world known authority in the field of creative thinking Edward de Bono. Lateral thinking is a way of creating new ideas and its essence is in creative progress, unlike vertical marketing which represents logical system of thinking.

Vertical marketing demands firstly the market to be defined whereas lateral marketing is based on finding out the possibilities for business expansion on the grounds of creating one or more new needs, target groups, ways of use or the situations which are not included in the previous market. Lateral marketing process is directed towards creation and market innovation.
Methodology of lateral marketing assumes focus definition for the realization of lateral progress, causing the lateral progress by making a gap and then thinking about the possible ways for the gap closure.

The final objective of Marketing Management is achieving customers' satisfaction oriented towards customers' loyalty. The basis for successful management oriented towards building a good relationship with the customer is made of:

- Involvement of executive managers and dedication to objectives which this type of management assumes,

- Successful measurement based on short-term quality management of services and on achieving a high degree of customers' satisfaction in the long run,

- Directions for individual initiative that provide the realization coordinated with general objectives and the strategy oriented towards building a relationship with customers.

Global market, burdened by fast changes, creates a strong competitive activity. Kotler (2009) speaks about the phenomenon of hypercompetitiveness, that assumes such market conditions in which technologies and offer are totally new, the standards and rules are becoming fluid and they cause competitive progress that is impossible to be stopped. Hypercompetitiveness is characterized by fast competitive progress and therefore competitors have to build new advantages in a short period of time in order to be better than their rivals.

In hypercompetitive conditions the application of standard marketing methods and techniques cannot give appropriate business results. This is even more significant in big and inert international corporations burdened by unnecessary administration and bureaucracy whose productivity is not able to follow global trends.

Traditional strategic approach implies a hypothesis according to which managers can predict future market trends precisely enough to choose a clear strategic direction just by using the set of analytical tools. On the other hand, when market flows are really turbulent and tend to become chaotic, this traditional approach is marginal and in real life even dangerous for the future of business organization. 
In order to avoid the influence of market turbulences Kotler suggests the application of a management system called Chaotic, (Kotler et al., 2014). According to Martinović (2009), the Management System Chaotic helps managers to reconsider the whole approach to management and marketing during recession and similar turbulent periods. Moreover, managers have to find a way to develop the system for early warning and identification of the first signs of changes, especially disastrous innovations and shocks. Then, it is important to make detailed, the worst, best and most expected scenarios by using the strategies for facing each of them, to cut costs strategically or to increase productivity, to secure market share in the fundamental consumer segment, to comprise strategic planning in shorter, three-monthly cycles in order to monitor the company's pulse better and easier so as to prevent potential disastrous consequences of leaving fundamental principles.

Taking into consideration the new marketing horizon oriented by further technological development and permanent changes in the environment, marketing model born in the new millenium is consisted of three dimensions of marketing comprehension: subphenomenon, phenomenon and superphenomenon (Acharol and Kotler, 2012).

Marketing seen as subphenomenon assumes customers' experiences and observation system. Customers feel products and services through their senses and the understanding of sensual experiences is transferred to the level of neurophysiology. In order to be able to follow this trend marketing will have to develop considerably wider basis of theoretical and methodological tools.

When we talk about marketing as a phenomenon we must observe that the days of vertical integration between producers and distributors have gone into the past and that nowadays distribution is performed through customers' networks, marketing networks, innovation and production networks. This means that we need rationalization and innovation outsourcing. In the future, the focus will be on micro production systems which will make products to satisfy demand near the very place of consumption.

Finally, when we talk about marketing as a superphenomenon we must stress that marketing ought to establish a sustainable model of consumers' society. New business approach implies giving advantage to welfare of the society and customers in relation to welfare of marketing management. The key issues of global marketing will be the issues of sustainability and poverty reduction.

\section{THE ANALYSIS OF THE ASPECTS OF MARKETING IMPLEMENTATION IN DOMESTIC ENTERPRISES}

Marketing theory has been more quickly and seriously developed in our country than marketing practice. As a term, marketing came into use in the late $70 \mathrm{~s}$ but the first significant theoretical contributions were noticed at the beginning of the 80s. Marketing, as a practice, started its development during the 90s along with the process of privatization but more serious advances were related to the beginning of the transition process after 2001.

Phillip Kotler, the most significant author of marketing, said about Serbian marketing theory and practice: "I haven't seen so far the country in which so much about marketing was known and spoken but so little and so bad was done. You need only one semester to get to know marketing but you need a whole life to master it" (Kramašić 2005).

On the other hand, marketing communication has first been developed as practice and then as theory which is logical and equal in all developed countries. The majority of domestic state-owned systems had their advertising sectors or economic propaganda which functioned seriously until the late 70s. In the same time, most journalist and publishing houses, such as Politika, Borba and Slovenian Delo, etc., had developed advertising sectors which worked as classical advertising agencies.

The real revolution in this sector took place in the time of economic relations liberation at the end of the $80 \mathrm{~s}$ when for the first time the transitional process began but unfortunately, the process was stopped due to political crisis and international sanctions in the 90s. At that time a lot of marketing agencies were opened and some of them were given international licence. In the late 90 s along with opening a considerable number of international marketing agencies this activity became the reality in some enterprises which 
worked on domestic market. The beginning of economic transitional process and the appearance of a number of foreign enterprises on the market of Serbia made conditions for marketing practice improvement.

No matter what the possibilities of applying foreign experiences were, the main characteristic of most domestic enterprises in the last two decades was the lack of appropriate marketing concept.

The main problems we face on domestic market in relation to marketing are the following:

- Lack of marketing logic adoption - marketing must be accepted not only as a business function but before all as a concept, business philosophy which has fundamental significance for every market oriented enterprise.

- Lack of integral marketing concept understanding - the acceptance of marketing only in principle can have contra - productive effects, mistification of marketing or voluntary approach. In a great part of domestic enterprises marketing serves as a business element which is used only to make a distance from the past and not for real needs - transfer towards market business and profit way of thinking.

- It is characteristic for domestic enterprises to understand marketing in the wrong way. Marketing is often made equal with promotion and advertising.

- Inappropriate understanding of investments in marketing - investing in marketing, above all in promotion, is not an expense but investment whose effects will be visible in the future through both positioning on the market and good reputation of the enterprise.

- Problems related to organizational structure - it is necessary to clearly define marketing position within an enterprise in relation to the functions with strategic sign, as well as to other functions (coordination and competences issues at macro level).

- Inadequate speed of new trends, methods and techniques adoption in marketing - taking into consideration previously mentioned facts as well as economic crisis from the early 90 s, it is obvious that even the enterprises with marketing behaviour do not have strength and space to accept all modern trends in the field of marketing quickly enough (Đorđević at al., 2001; Đorđević and Ćoćkalo, 2010).
Most domestic executive managers put the equation sign between marketing and promotion activities and some of them go even further and equilize marketing with sale. These are typical mistakes but they are not made only in domestic enterprises on relatively undeveloped markets, such as in transitional countries where Serbia belongs to. Similar problems can occur in some developed counties as well, but only in new enterprises or in micro and small enterprises in which marketing function is often the part of organisational sector dealing with marketing.

Wrong understanding of marketing is typical for transitional countries and developing countries without free markets. Misunderstanding of marketing logic as a business concept and especially business function leads towards the next problem - personalization of marketing by managers/executives. General managers think they know best how marketing functions so they directly conduct all marketing activities. The next wrong step is inappropriate selection of those who should deal with marketing - for example, in the sector of small and mid-size enterprises marketing is a job of "some relatives" who already work in the enterprise while in public sector politics plays a significant role.

The problem is, certainly, in the wrong perception of reality which is the result of several decades long business shortsight - wrong set model of socialist self-management has been slightly redesigned into the first transition during the 90s with disastrous results, and the real transition which started in 2001 was not developed sufficienly satisfactory although it involved the greatest part of enterprises. According to Edward de Bon (2008), if the perceptions are wrong, the answers will be nonsense no matter how good is your logic. Wrong perceptions of domestic executives were multiplied even more by impossibility of creating equal conditions for all in the economy that did not encourage private initiative.

Inertness seems to be one of the main problems in management in relation to accepting modern methods and techniques of management quickly and appropriately. Most managers are guided by inertness in their daily behaviour, in other words, they like routine and making decisions according to certain standard principles. 
D. Đorđević et al. The analysis of marketing concept implementation
in domestic enterprises

A lot of factors contribute to making strategic inertness but three of them represent a real threat. The first is a tendency of management teams to ignore or deny the need for strategy renewal. The second is the lack of convincing alternatives to the current state and, finally, the third is rigidness in distribution which makes regrouping of talents and capital harder (Hamel 2009).

Domestic enterprises are still at the level of vertical marketing concept. Unfortunately, not all domestic enterprises are at that level, only those which successfully finished transformation process and some enterprises with autochthonous domestic private capital. Domestic businessmen generally need lateral advance in thinking - from thinking about the past towards proactive thinking.

\section{GUIDELINES FOR MARKETING IMPROVEMENT IN DOMESTIC ENTERPRISES}

Transformation of domestic enterprises from relatively undeveloped organizations, from the standpoint of management theory and practice, towards the organizations with developed functions of research and development, quality management and marketing, based on system approach to organization and management, represents the only choice for improving business appearance on the international market.

Therefore, a special attention must be paid to implementation of new marketing approaches, both in conceptual and organizational sense.

According to some authors (Vračar, 1996), the adoption of marketing concept is not an act but the process of enterprise's adjustment to business requirements and functioning of modern market economy. It involves a long-term process of accepting foreign experiences and business practise based on current theoretic achievements.

Domestic enterprises must accept this modern marketing concept in their business on domestic market. Marketing ought to be clearly positioned within internal environment of business functions in the enterprise as a function of strategic significance, together with research and development function and quality management function. The stress is on wider acceptance of a new marketing model, characterized by technological development and represented in marketing communication component through the model of integrated marketing communication. New approaches to marketing research and its application in theory and practice represent the reality of modern business and they are the part of the world economy globalization process.

Domestic enterprises have to get rid of their old way of thinking limited by domestic market, comprehension of business and business experiences (according to the motto "if something is functioning, it shouldn't be changed"). The common approach that the international market is seen as absolutely homogenuous has to be left and furthermore, the international market should be viewed in the light of the most significant international tendences, structural and technological changes, knowledge innovations with all specific features and local characteristics.

Drucker (2006) thinks that the most frequent failure of executive managers is their disability and unwillingness to make changes according to the requirements of the new position. On the other hand, successful executive managers observe people, including themselves, as a potential. They are aware that only power makes results. Domestic executives obviously have it. This statement seems logical because of the fact that in domestic economy collective management which fulfilled political requirements was dominating over 50 years. In some situations, political leaders returned and worked again in the economy, but it was not enough to develop leadership in business organizations.

According to the results of the research which analized the implementation of modern management techniques in domestic enterprises (Bešić at all, 2013), the following management methods and techniques should be implemented in domestic business organizations so as to improve business efficiency and competitiveness:

- Database Management 18.4\%,

- Quality Management System - 17.6\%,

- Corporate Social Responsibility - 17.6\%,

- Relationship Marketing - $16.8 \%$ and

- Benchmarking $-12.6 \%$.

Management methods and techniques identified by domestic enterprises managers as significant for business performance of their enterprises are all based on knowledge. New management paradigm at global level is based on the process of knowledge productivity improvement. Database 
Management is in fact creating and storing information for the needs of managerial decisions and a piece of information represents knowledge in motion. Quality Management System in its essence involves the need for permanent knowledge productivity improvement, primarily through education for quality. The concept of Corporate Social Responsibility assumes learning about needs and requirements of other interest groups from business environment. Relationship Marketing finally means knowledge management. Marketing is a key instrument for making knowledge more productive. Benchmarking implies a technique of learning on other people experiences, primarily the best ones. It gives the best answers about temporary market position of the organization. The result of this process ought to be the creation of strategic variants for market positioning. Quality Management System, on the other hand, represents the need for permanent knowledge productivity improvement, predominantly through education for quality.

On the grounds of the mentioned data can be concluded that, even in crisis, top managers are completely aware that investment in employees and their knowledge as well as investment in modern technologies and equipment are the most essencial factors in defining competitive ability of their enterprise in modern business.

The following general recommendations for improving marketing activities of domestic enterprises are distinguished:

- Necessity for permanent knowledge innovation of all employees, predominantly marketing experts, who should be taught the most advanced world experiences and modern methods and techniques of marketing management,

- Necessity of planning approach to marketing activities,

- Necessity of permanent quality improvement, organization functioning and management innovativeness are imperatives of business performance in modern society.

Marketing improvement predominantly as a business function and business practice is directly linked to the implementation of modern management methods and techniques, especially the newest achievements in the field of marketing theory and practice. It is necessary to transfer and improve knowledge of all employees, especially leaders. On the other hand, certain changes in education of students, future experts ought to be made, (Ćoćkalo et al., 2015).

There are three ways of increasing enterprise's creativity:

- Employment of naturally creative people who would be given freedom in their work,

- Creativity stimulation by means of using a great number of well tested methods,

- Engagement of external experts who would enable the appearance of new, interesting ideas (Kotler, 2004).

The issue of marketing function improvement in domestic organizations, especially in domestic enterprises, is reduced to the issue of knowledge improvement and knowledge productivity.

According to some opinions (Bešić at al., 2007, 2015), the key role in enterprises transformation in transitional countries should have top management whose task is to change the current state and the way of work - in Taylor's words, domestic economy needs mental revolution. The statement is related to both employees and leaders who need to accept the fact that knowledge is the key business resource and that managing an organization means in fact managing knowledge.

Domestic managers have to become efficient and then to make other employees efficient, too. Generally speaking, newly made framework of human society asks for people who are representatives of successful synthesis of knowledge, skills and attitude. This threedimensional approach is conditioned by modern business performance. An individual must satisfy a wide spectrum of features in order to successfully respond to tasks imposed by modern organization. These requirements are becoming increasingly important in the activities related to marketing.

\section{CONCLUSION}

Successful business of an organization in the new era will depend on the organization's relationship towards the increasing need for knowledge and implementation of the newest technological achievements in the process of organizational management. The old-fashioned models of organizational management are exchanged by new, more advanced models, better adjusted to modern 
market conditions. The future belongs to the most flexible, innovative and adaptable enterprises.

According to Adizes (2006), success comes from inside. If we are strong inside, we'll be able to solve every outside problem and accept it as an opportunity. On the other hand, success of any system, micro or macro, any human being, family, organization or society can be predicted by means of only one factor - the relationship between outside and inside marketing. Success is the function of marketing.

Relationship Marketing represents a significant paradigmatic step ahead in the field of marketing theory and practice. It recognizes the significance of different participants - suppliers, employees, distributors, dealers, retailers, who are collaborating in order to distribute the best value to their targeted customers.

Competitiveness at international level is achieved on the grounds of quality business performance, product differentiation and relevant marketing communication, (Đorđević et al., 2012).

Globalization is the only way out for all countries in transition whereas the focus must be on development of industrial production. Newly industrialized countries have just worked on the development of industrial production and the offer of their industrial products at global markets. Inclusion into global flows is an imperative for all transitional countries and for domestic economy as well. It implies an appropriate implementation of all modern management methods and techniques, especially marketing.

Competitiveness of domestic enterprises is not satisfactory and the main reason can be found in insufficient efforts that are invested in development of business quality (implementation of quality concept in organizational structure) and marketing. According to (Đorđević at al., 2011), business performance of domestic enterprises must be founded on implementation of management techniques which support competitiveness, innovativeness and flexibility as well as on knowledge improvement of employees, especially top management.

Domestic enterprises have to use international experiences, standards and globally acknowledged business practice in the process of their business internalization. It is therefore, necessary to implement these management techniques that potentiate long-term commitment towards competitiveness, such as marketing, quality management, benchmarking, etc.

According to de Bon (2008), the process of thinking is an operational skill. Although people have to think in school and after finishing it, the practice itself, unfortunately, doesn't automatically result in improved skill. In other words, if you practice bad thinking for years, you will become bad and unskilled thinker. Domestic managers can be used as a model for this contention of a famous theorist and practitioner of lateral thinking - bad thinkers who operate contrary to modern world leaders. As for the employees who deal with marketing in domestic enterprises, they are mainly individuals without much education and skills from this field. There is a many year long comprehension on domestic market that anyone can deal with management and marketing because these skills and knowledge, viewed from laics' standpoint, seem as ordinary, daily activities. The main achievements in this field have been made by foreign marketing agencies or international corporations that collaborated with them.

In this sense, domestic enterprises need experts with thorough knowledge on management and marketing methods and techniques.

\section{REFERENCES}

Adizes, I. (2006). Mastering Change [in Serbian]. Novi Sad: Asee.

Acharol, R. S., \& Kotler, P. (2012). Frontier of the marketing paradigm in the third millenium. Journal of academic marketing science, 40(1), 35-52.

Brookes, R., \& Little, V. (1997). The New Marketing Paradigma - What does customer focus now mean? Marketing and Reserch Today, 25(2), 96-105.

Bešić, C., \& Đorđević, D. (2015). Corporate Social Responsibility [in Serbian]. Čačak: FTN.

Bešić, C., Krnjević-Mišković, Z., \& Đorđević D. (2013). The Role Of Knowledge In The Development Process Of Competitive Ability Of Domestic Companies On The Global Market. International Journal of Economics \& Law, 3(7), 17.

Bešić, C., Sajfert, Z., \& Jakovljević, L. (2007). Leadership as a prerequisite to improve the competitiveness of domestic businesses [in Serbian]. Paper presented at the Conference "Management and Leadership", Belgrade.

Ćoćkalo, D., Đorđević, D., Bešić, C., \& Bogetić, S. (2015). Undergraduate Business Students' Attitudes Towards CSR and Competitiveness of Serbian 
D. Đorđević et al. The analysis of marketing concept implementation in domestic enterprises

Economy. Journal of Engineering Management and Competitiveness (JEMC), 5(1), 12-20.

de Bono, E. (2008). Thinking course [in Serbian]. Novi Sad: Asee.

Drucker, P. (2006). Management Skills for the Effective Manager [in Serbian]. Novi Sad: Asee.

Đorđević, D., Anđelković, M., \& Bogetić S. (2001). The restructuring of domestic companies [in Serbian]. Belgrade: KAS.

Đorđević, D., \& Ćoćkalo, D. (2010). Fundamentals of Marketing [in Serbian]. Zrenjanin: Technical faculty "Mihajlo Pupin".

Đorđević, D., Ćoćkalo, D., Bogetić, S., \&, Bešić C. (2012). Development of business excellence and competitivness of domestic companies. International Journal of Advanced Quality, 40(4), 36-41.

Đorđević, D., Ćoćkalo, D., \& Bogetić S. (2011). New model of competitiveness management and development of domestic enterprises [in Serbian]. Paper presented at the International Convention on Quality - UASQ 2011, Belgrade.

Hamel, G. (2009). The Future of Management [in Serbian]. Novi Sad: Asee.
Kotler, P. (2004). Marketing Insights from A to Z [in Serbian]. Novi Sad: Asee.

Kotler, P., \& Caslione J. (2009). Chaotics: The Business of Managing and Marketing in the Age of Turbulence [in Croatian]. Zagreb: Mate.

Kotler, F., \& de Bes, F.T. (2005). Lateral Marketing: New Techniques for Finding Breakthrough Ideas [in Serbian]. Novi Sad: Asee.

Kotler, P., Keller, K.L., \& Martinović M. (2014). Marketing management [in Croatian]. Zagreb: Mate.

Martinović, M. (2009, 10.09.2009). The worst reaction to the sudden turbulence and recession is a broad cost-cutting [in Croatian]. Lider.

Kramaršič, M. (2005). Sparks of marketing [in Serbian]. Belgrade: Kramaršič Miloš.

Vračar, D. (1996). The firm's communication activities the neglected instrument of the Yugoslav agribusiness marketing [in Serbian]. Paper presented at the International conference on Marketing in Agribusiness, Belgrade.

\title{
ANALIZA PRIMENE MARKETING KONCEPTA U DOMAĆIM PREDUZEĆIMA
}

\begin{abstract}
Globalno tržišta i svremeni uslovi poslovanja zahtevaju od preduzeća promenu poslovne filozofije i adekvatne načine ponašanja u domenu poslovne prakse. U informatičkom društvu znanje postaje osnovni resurs privređivanja. Marketing omogućava upravljanje znanjem, odnosno stvara mogućnost za povećanje produktivnosti znanja ostalih poslovnih funkcija preduzeća. Marketing odnosa označava značajan pomak u pristupu marketingu, od razmišljanja isključivo u kategorijama konkurencije i konflikta, ka razmišljanju u kategorijama međuzavisnosti i saradnje. Domaća preduzeća imaju probleme sa postizanjem konkurentske sposobnosti na globlanom tržištu, a jedan od značajnih uzroka ove pojave jeste neadekvatna primena marketing koncepta i savremenih metoda i tehnika upravljanja marketingom. Ovaj rad donosi prikaz aktuelnih globalnih trendova u teoriji i praksi marketinga i marketing menadžmenta, odnosno kritičku analizu i predloge za unapređenje domaće marketing prakse.
\end{abstract}

Ključne reči: Marketing, Konkurentnost, Globalno tržište, Upravljanje, Znanje. 